\title{
Interannual and Seasonal Variations in Estuarine Water Quality
}

\author{
Cibele R. Costa ${ }^{1}$, Monica F. Costa ${ }^{1 *}$, David V. Dantas ${ }^{2}$ and Mario Barletta ${ }^{1}$ \\ 1 Laboratório de Ecologia e Gerenciamento de Ecossistemas Costeiros e Estuarinos, Departamento de Oceanografia, \\ Universidade Federal de Pernambuco, Recife, Brazil, ${ }^{2}$ Laboratório de Tecnologia e Ciência Pesqueira, Departamento de \\ Engenharia de Pesca e Ciências Biológicas, Universidade do Estado de Santa Catarina, Laguna, Brazil
}

\section{OPEN ACCESS}

Edited by:

Alice Newton,

University of Algarve, Portugal

Reviewed by:

Miguel Cañedo-Argüelles,

University of Barcelona, Spain

Chris S. Hallett,

Murdoch University, Australia

*Correspondence:

Monica F. Costa mfc@ufpe.br

Specialty section:

This article was submitted to Marine Ecosystem Ecology, a section of the journal

Frontiers in Marine Science

Received: 23 February 2018

Accepted: 08 August 2018 Published: 05 September 2018

Citation:

Costa CR, Costa MF, Dantas DV and

Barletta M (2018) Interannual and

Seasonal Variations in Estuarine Water

Quality. Front. Mar. Sci. 5:301.

doi: 10.3389/fmars.2018.00301
Anthropic processes degrade quality of estuarine environments, resulting in a worrying form of water pollution. The objective of the study was to describe and discuss interannual and seasonal changes of water quality based on indicators monitored in Goiana River estuary, as well as identifying the main drivers of such changes. We considered three estuarine areas or habitats (upper estuary, middle estuary and lower estuary), and two seasons (dry and rainy) for anchoring sample design. The information collected for surface and bottom water include water temperature $\left({ }^{\circ} \mathrm{C}\right)$, salinity, dissolved oxygen ( $\left.\mathrm{mg} \mathrm{L}^{-1}\right)$, saturation (\%) and Secchi depth $(\mathrm{cm})(n=864)$. The monthly total rainfall $(\mathrm{mm})$ was compiled from public database. Multivariate analyses highlight inter dependency among these parameters. Water quality was reduced in dry periods (including episodes of hypoxia), but generally increased toward the mouth of estuary. Rainfall is the most important factor in the renewal and maintenance waters of small tropical estuaries. Regions most sensitive to climate change where water resources are depleted and/or compromised should pay even more attention to upcoming changes in rainfall (seasonal) and climatic patterns in addition to better water management practices.

Keywords: physico-chemical parameters, sample design, tropical estuaries, aquatic habitat conservation, hypoxia

\section{INTRODUCTION}

Water is an indispensable natural resource for human survival and essential for the development of most our activities (World Health Organization, 2011, 2014). Its abundance on Earth's surface gave rise to the thought that it would be an inexhaustible resource, not being initially considered as deserving of conscious use, or reason to avoid the significant shift of the demand/availability ratio to an unfavourable condition (Brooks et al., 2006; Haynes et al., 2007).

Many communities emerged close to where water could be easily obtained to ensure food and maintenance of the population. Estuaries are examples of environments that provide the necessary means for the development of human communities (World Health Organization, 2014) and indeed support large populations. These ecosystems are in a transitional range between the fluvial and marine environments, influenced by the maritime amplitude, which causes a marked variation of its environmental parameters, such as nutrients and salinity (Kennish, 1991, 1998). They also have the capacity to shelter numerous species, from the juvenile forms to adult phases, which use the environment for feeding, breeding or protection from predators; in addition to resident species, that spend their entire life cycle in estuaries, many of these resources reach high economic and social values (Kennish, 1991, 1998; Barletta and Dantas, 2016).

Water quality loss in estuaries are, therefore, one of the worst forms of water pollution (Karydis and Kitsiou, 2013). The main causes of decline in quality of the estuarine aquatic bodies are 
related to water subtraction and releases of agricultural, domestic and industrial effluents (Alexakis, 2011; Brockmeyer and Spitzy, 2011), altering the physical, chemical and biological properties of water (Kitsiou and Karydis, 2011; Karydis and Kitsiou, 2013), and consequently dropping the concentrations of dissolved oxygen (Yin et al., 2004; Mudge et al., 2007; Breitburg et al., 2009).

Dissolved oxygen in marine and coastal waters can directly influence environmental health (Mudge et al., 2007; Breitburg et al., 2009). Episodes of low concentrations of dissolved oxygen in the water are considered cases of hypoxia (Breitburg et al., 2009; Zhang et al., 2010). These events have been recorded and studied in literature, mainly due to the occurrence of effluent and organic matter flows into coastal waters (Attrill and Power, 2000; Tett et al., 2003; Yin et al., 2004; Roselli et al., 2013). Reduced oxygen in waters affects the ecology of diverse populations of organisms (growth, distribution, recruitment, reproduction, and survival) and the state of local pollution (Mudge et al., 2007; Breitburg et al., 2009). The reduction of dissolved oxygen is a strong indicator of poor water quality and needs to be monitored and treated.

The assessment of water quality parameters is a tool for maintaining the best possible water conditions across entire basins, including estuaries and adjacent coastal waters (Kitsiou and Karydis, 2011; Karydis and Kitsiou, 2013). Consistent information on water quality and its patterns of change is the key to better manage and use these resources rationally (World Health Organization, 1996; Karydis and Kitsiou, 2013). Being capable of accommodate changes (episodic or permanent) to managerial plans require a solid knowledge about the drives of water quality and natural resources availability at different timescales.

The objective of the present study was to describe and discuss the interannual and seasonal changes of water quality based on indicators monitored in the Goiana River estuary, as well as identifying the main drivers of such changes and the main hypothesis is the estuary of the Goiana River presents seasonal and interannual changes in water quality in its different habitats.

\section{METHODS}

\section{Study Area}

The main activities developed along the Goiana River basin are sugarcane agro-industry, industrial activities and urban occupation. Effluents are discharged directly into the water, causing damages to the full extent of the basin, in addition to water use for public supply and irrigation (Garlipp et al., 2010; CPRH-Agência Estadual de Meio Ambiente e Recursos Hídricos., 2015; Costa et al., 2017). There are two gauges which measure river flow upstream (Brazilian Water Agency gauges \#39080000 and \#39084000). Year-round average flow at these tow gauges are 11.0 and $8.8 \mathrm{~m}^{3} \mathrm{~s}^{-1}(\sim 90 \%$ catchment area), but it can vary from $3.5 \mathrm{~m}^{3} \mathrm{~s}^{-1}$ (dry season) to $60 \mathrm{~m}^{3} \mathrm{~s}^{-1}$ (rainy season) (Arruda-Santos et al., 2018).

The Goiana River estuary $\left(7^{\circ} 30^{\prime} \mathrm{S}-34^{\circ} 47^{\prime} \mathrm{W}\right)$ (Figure 1) is a tropical shallow estuary that supports important ecological processes (Barletta and Costa, 2009; Dantas et al., 2010; Silva et al., 2013) and is under legal protection as an extractive reserve aimed at traditional fishers populations. There, the impact of greater significance is caused by sugarcane crops, prawn farming and lime extraction, which are connected directly to degradation of the mangrove flooded forest (Barletta and Costa, 2009; Garlipp et al., 2010; CPRH-Agência Estadual de Meio Ambiente e Recursos Hídricos., 2015). Despite recent trends in economic diversification, the area remains strongly linked to primary activities.

According to Kjerfve (1990), the main axis of an estuary can be sectioned into large compartments or areas-upper, middle, and lower-considering its morphology and salinity, since riverine environments down to adjacent coastal areas. Each section of the main channel is an habitat (Barletta et al., 2005; Lima et al., 2014), with different biogeochemical behaviour, plant and animal communities, giving rise to an ecological gradient (Attrill and Rundle, 2002; Barletta and Dantas, 2016). Composed of a combination of rivers, streams, ponds, tidal channels, islands, wetlands and flooded mangrove forests, this estuary accommodates a diverse aquatic fauna (fish, molluscs, crustaceans) (Barletta and Costa, 2009; Dantas et al., 2010; Lima et al., 2014) with high conservation, social and economic importance. The main channel has a total length of $\sim 25 \mathrm{~km}$ (Barletta and Costa, 2009; Dantas et al., 2010; Costa et al., 2017). The upper estuary varied in depth from 1.2 to $11.6 \mathrm{~m}$, middle estuary ranged from 1.2 to $10.1 \mathrm{~m}$ and the lower estuary had a depth variation of 1.0 to $9.1 \mathrm{~m}$.

\section{Data Acquisition}

The sampling strategy adopted in this study was successfully used by several authors (Barletta et al., 2005, 2008; Dantas et al., 2010; Lima et al., 2014), attesting for the robustness of sample design. The strategy was implemented from 2006 to 2009 in this estuary. Based on previous literatures (Lima et al., 2014) and a previous sampling that covered the whole extent of the main estuarine channel, were recognized three areas (upper, middle and lower estuary) and two seasons (dry and rainy). The months chosen for this study were those at end of each seasons, when the environment presents clearer responses to the environmental stressors (Figure 2A). During the pilot sampling, water temperature, salinity, dissolved oxygen, Secchi depth and water depth were probed to define the limits of each area.

The data for the present study was collected for surface and bottom waters ( 6 samples/area, in the central area of the main channel; once a month; during 3 months in each season). So, each month has 18 replicas per area, per month per year; $n=864$. Measurements include water temperature $\left({ }^{\circ} \mathrm{C}\right)$, salinity, dissolved oxygen $\left(\mathrm{mg} \mathrm{L}^{-1}\right)$ and oxygen saturation (\%) (measured with a WTW LF 197, Wissenschaftlich Technische Werkstätten with a $20 \mathrm{~m}$ cable) and Secchi depth $(\mathrm{cm})$. Monthly total rainfall (mm) was compiled from public database (www.apac.gov.pe.br), collected from a weather station located $10 \mathrm{~km}$ south of the city of Goiana.

\section{Statistical Analysis}

Data collected were processed into an orthogonal matrix for analysis $(n=864)$. Cochran's test was used to check the homogeneity of variances. 


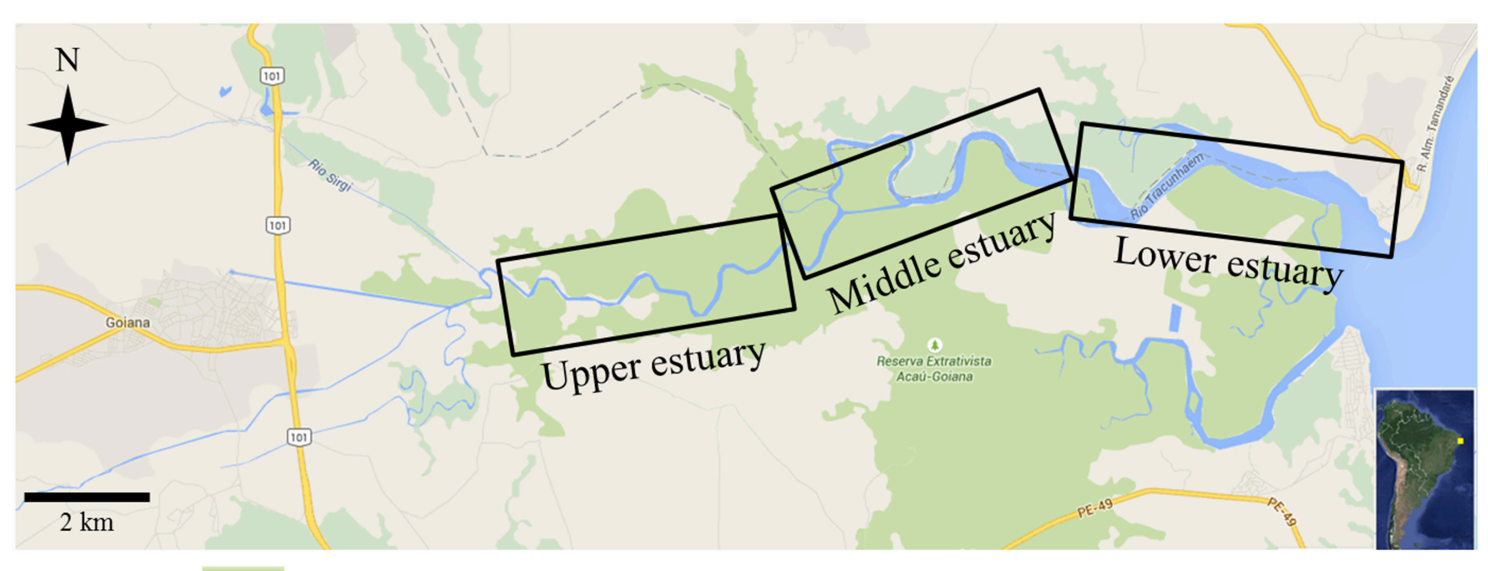

Mangrove forest

Atlantic forest

Urban perimeter

Sugar cane plantations and mills

FIGURE 1 | Location of Goiana River estuary, showing upper estuary, middle estuary, and lower estuary along the main channel. Source: Google maps, adapted.

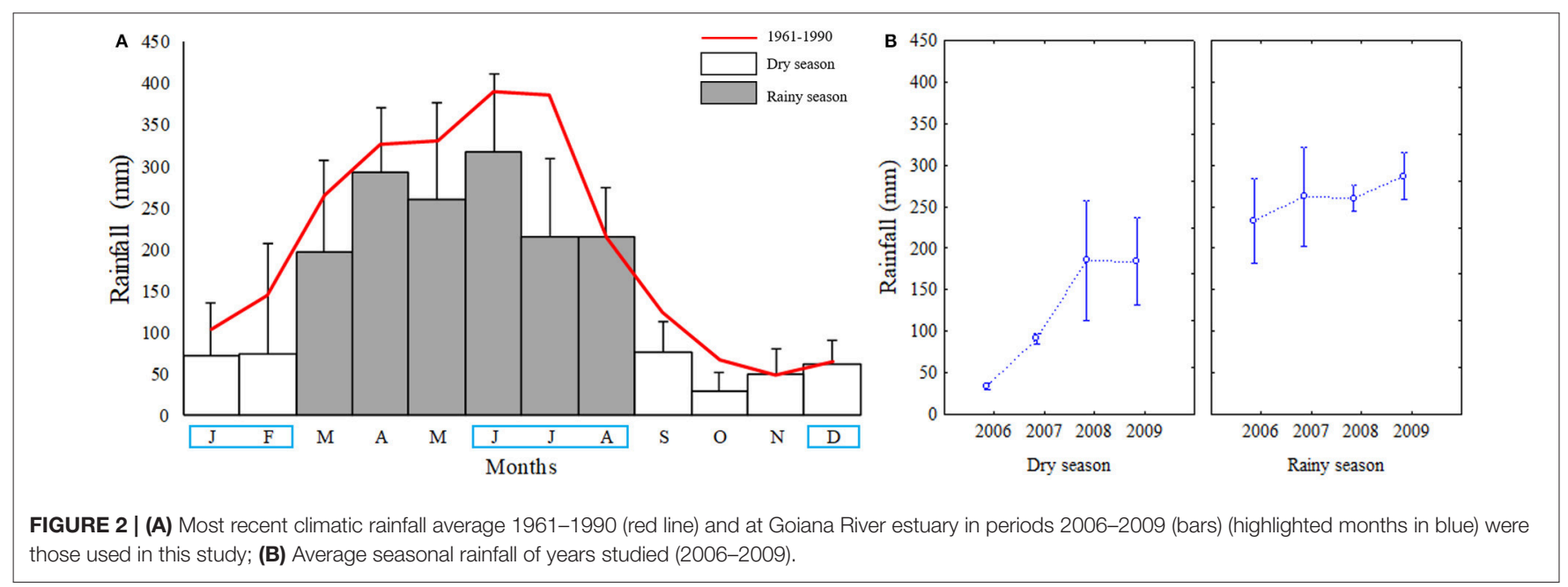

The original data were Box-Cox transformed to ensure it conformed to a normal distribution.

The analysis of variance (factorial ANOVA with a 5\% level of significance) were carried out. This was used to determine whether significant differences in categorical predictors (factors) occurred in years $(2006,2007,2008$, and 2009), areas (upper, middle and lower estuary) and seasons (dry and rainy) and depth in water column (surface and bottom). The variables (water temperature, salinity, dissolved oxygen and oxygen saturation) were first studied and analysed separately for their individual behaviours (see Supplementary Material) and detect possible differences between surface and bottom waters. With the ANOVA results, it was possible to observe that there were no differences and therefore, depth was not further considered.
Samples from surface and bottom waters were treated as replica, increasing the sample number from six to twelve (see above section Data acquisition).

Subsequently, a multivariate analysis of variance (MANOVA) analysis was performed, excluding the depth factor. A posteriori Bonferroni's test was used to determine which means were significantly different at the $5 \%$ level of significance.

Clusters were determined based on similarity matrix using the method of complete linkage with Euclidean distance and a principal components analysis was made using a 95\% confidence interval, for all variables studied. A multivariate analysis highlights the inter dependency among water physico-chemical parameters. For these analyses, observations were homogenized in averages $(n=24)$, due to large number of samples $(n=864)$, 
allowing for better observation and interpretation of results. Averages were made between samplings of same spatiotemporal condition (year, area and season-replica).

\section{RESULTS}

MANOVA showed that salinity, temperature, dissolved oxygen, saturation and Secchi depth differ significantly between seasons, areas and years. The interactions year vs. season vs. area also significantly differ for these variables $(F=3.4, p=0.0000)$ (Table 1). Such interactions suggest that the physico-chemical parameters are affected by the years, the seasonality and the main channel area.

Monthly total rainfall in the studied period, ranged from 20.2 to $364.0 \mathrm{~mm}$. In the dry season, averages were between 33.9 $\pm 8.5 \mathrm{~mm}$ and $184.1 \pm 106.0 \mathrm{~mm}$, while in the rainy season range was $233.4 \pm 102.3 \mathrm{~mm}$ to $286.6 \pm 57.2 \mathrm{~mm}$ (Figures $\mathbf{2 A , B}$ ). Among dry seasons, 2006 presented the lowest rainfall (33.9 \pm $8.5 \mathrm{~mm})$. Dry seasons of $2008(185.2 \pm 144.5)$ and 2009 (184.1 \pm 106.0 ), presented very similar behaviour regarding the rainy seasons of all years studied (and in comparison, with the climatic average 1961-1990). Rainy seasons presented a very similar pattern in all the studied years, varying less than dry seasons during the study period in respect to total monthly rainfall.

Water temperature varied from 25.3 to $31.4^{\circ} \mathrm{C}$, presenting values with small variation between years and areas, and higher in dry season (Figure 3). Variations were less prominent in rainy season. Upper and middle areas showed no differences but were different from lower area. Year 2009 was different from the others. The seasons were also different (Table 1).

Salinity varied from 0 to 36.9 , with 121 of the 432 sampled values being equal to zero, especially in areas upper and middle

TABLE 1 | Summary of the MANOVA ( $F=3.4 ; g f=859)$ and Bonferroni's test results for water temperature, salinity, Secchi depth, dissolved oxygen, and oxygen saturation for year - 2006 (06), 2007 (07), 2008 (08), 2009 (09) for estuarine area - upper $(\mathrm{U})$, middle $(\mathrm{M})$, lower $(\mathrm{L})$ - for season - dry $(\mathrm{D})$, rainy $(\mathrm{R})$.

\begin{tabular}{|c|c|c|c|c|}
\hline \multicolumn{5}{|c|}{ Source of variance } \\
\hline Parameters & Year (1) & Area (2) & Season (3) & $\begin{array}{c}\text { Mean } \\
\text { interactions }\end{array}$ \\
\hline \multirow[t]{2}{*}{ Water temperature } & $\star \star$ & $\star \star$ & $\star \star$ & $\star \star$ \\
\hline & 06070809 & U M L & $\mathrm{D} \mathbf{R}$ & $1 \times 2 \times 3$ \\
\hline \multirow[t]{2}{*}{ Salinity } & 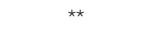 & $\star \star$ & $\star \star$ & ** \\
\hline & $\underline{07} \underline{08} 0609$ & $\cup M \mathbf{L}$ & $D \mathbf{R}$ & $1 \times 2 \times 3$ \\
\hline \multirow[t]{2}{*}{ Dissolved oxygen } & $\star \star$ & $\star \star$ & $\star \star$ & $\star \star$ \\
\hline & 06070809 & U M L & $\mathrm{D} \mathbf{R}$ & $1 \times 2 \times 3$ \\
\hline \multirow[t]{2}{*}{ Oxygen saturation } & $\star \star$ & $\star \star$ & NS & $\star *$ \\
\hline & 06070809 & U M L & & $1 \times 2 \times 3$ \\
\hline \multirow[t]{2}{*}{ Secchi depth } & $\star \star$ & $\star \star$ & $\star \star$ & $\star \star$ \\
\hline & 06070809 & $\cup M \mathbf{L}$ & $\mathrm{D} \mathbf{R}$ & $1 \times 2 \times 3$ \\
\hline
\end{tabular}

$N S$, non-significant differences ( $p>0.05)$; ${ }^{*} p<0.05$; ${ }^{* *} p<0.01$; differences among year, area and season were determined by Bonferroni's test $(p<0.05)$ post-hoc comparisons. during rainy season. Areas and seasons were different (Table 1; Figure 4).

Dissolved oxygen varied from 1.4 to $10.4 \mathrm{mg} \mathrm{L}^{-1}$ in the period, with the highest averages concentrated in lower estuarine portion (Figure 5). Figure 5 shows an histogram with the normal distribution of number of observations of dissolved oxygen values obtained $(n=864)$. It is observed a wide range, from 0 to $11 \mathrm{mg} \mathrm{L}^{-1}$, but with a high number of observations between 4 and $6 \mathrm{mg} \mathrm{L}^{-1}$. For this parameter, $4.2 \%$ of the values were between 0 and $2.0 \mathrm{mg} \mathrm{L}^{-1}$ (critical); $42.8 \%$ between 2.1 and $5.0 \mathrm{mg} \mathrm{L}^{-1}$ (acceptable) and; $53.0 \%$ of the values were $>5 \mathrm{mg} \mathrm{L}^{-1}$ (safe) (Conselho Nacional de Meio Ambiente, 2005) (Figure 5). The seasons were different, and so were the lower area and year 2009 (Table 1).

Oxygen saturation showed values between 17 and $123.7 \%$ and followed the trend presented by dissolved oxygen (Figure 6). There were no significant differences between seasons (Table 1).

Secchi depth varied from 12 to $276 \mathrm{~cm}$, showing large variations between the years in the dry seasons, while in rainy seasons measurements, once again showed less variability (Figure 7). All factors (year, area, and season) were significantly different for this variable (Table 1).

In the cluster analysis (Figure 8), observations were grouped into 2 major groups, I e II. Group I was subdivided into 2 subgroups. Subgroup IA, was subdivided in IA1 comprised samples from 2008 in dry season in lower area and IA2, were samples in dry season in upper and middle areas in 2008 and 2009 and lower area in 2009. Subgroup IB, was subdivided in IB1, samples taken in 2009, in three areas, during rainy season and IB2, comprised samples from 2006, 2007, and 2008 in three areas during the rainy season. Group II presented two subgroups: IIA, which comprised samples from 2006 and 2007, lower area in dry season. In subgroup IIB were samples from years 2006 and 2007, in upper and middle areas, during dry season.

Interpreting the principal components analysis, $76.73 \%$ (PC1 and PC2) of the variation of data are satisfactorily explained, revealing inter-relations among variables. According to Clarke and Warwick (2001), a PCA must explain $70 \%$ or more initial variations in a data set. If so, it is a reasonable interpretation of the phenomenon, or global structure of interactions. In this case, PC1 explained $44.70 \%$ of the total variance, was formed mainly by the variables temperature, salinity, rainfall and seasons of the year (Table 2), while PC2 represented $32.03 \%$, formed mainly by the dissolved oxygen and its saturation (Table 2). The weights plot (Figure 9A) show the distribution of variables and the scores plot (Figure 9B) the distribution of replica.

\section{DISCUSSION}

Water temperature was strongly marked by seasonality. The difference between years was small, but the difference between seasons was highlighted. The estuary is located in a tropical area (Barletta and Costa, 2009; Costa et al., 2017), which favoured high water temperatures throughout the year. This factor can affect the dissolution of gases as oxygen in the water, decreasing their availability for biological and chemical processes (Yin et al., 2004; 


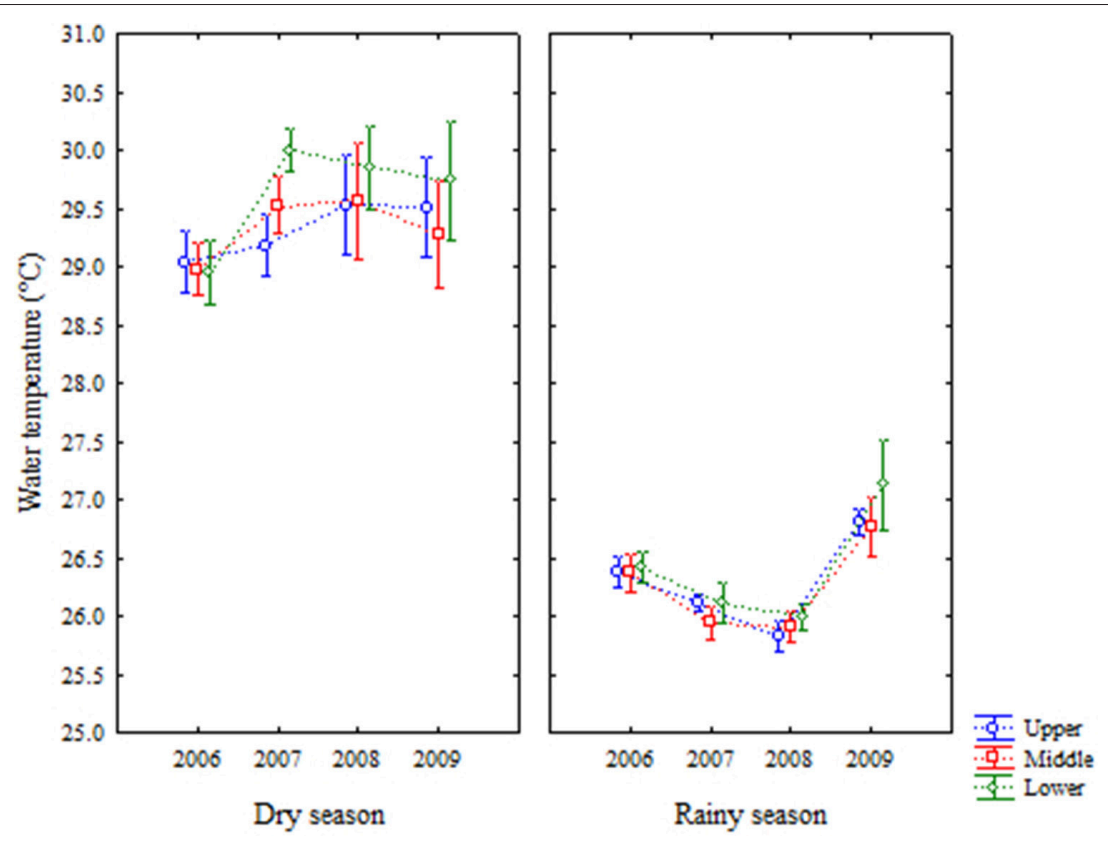

FIGURE 3 | Average ( \pm standard deviation) of temporal (interannual and seasonal) variations of water temperature at the Goiana River estuary from 2006 to 2009.
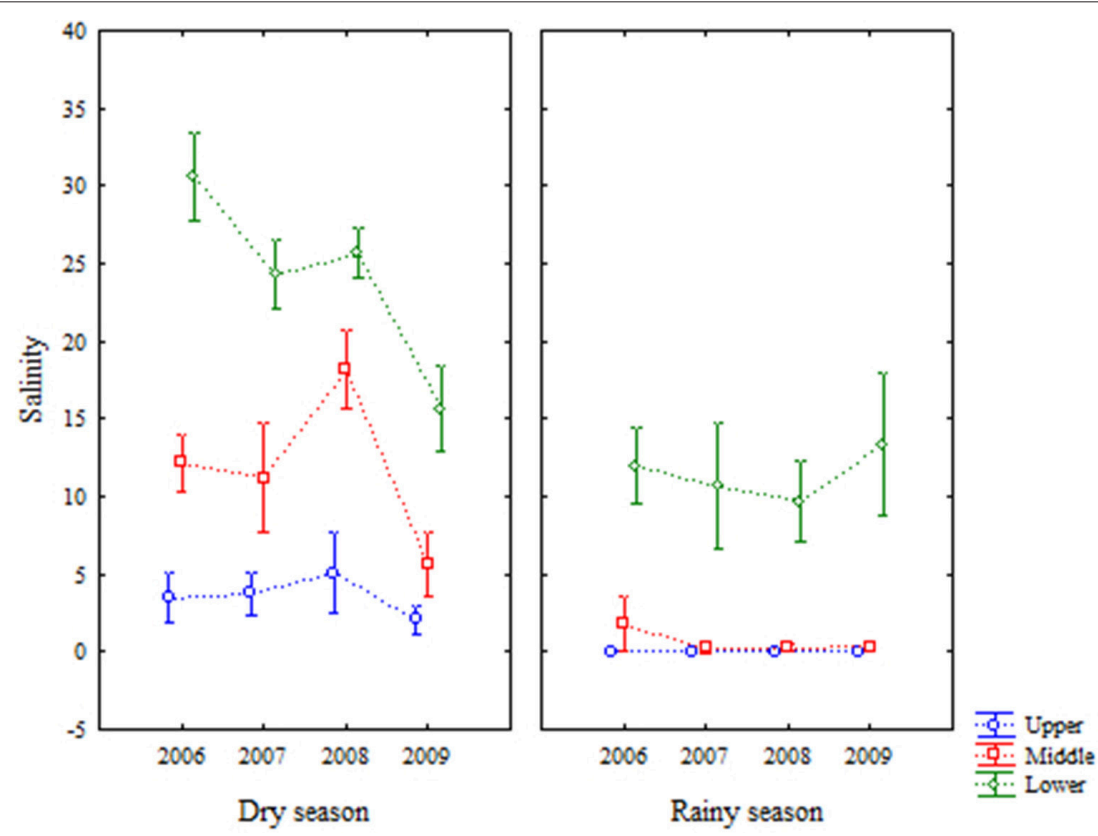

FIGURE 4 | Average ( \pm standard deviation) of temporal (interannual and seasonal) variations of salinity at the Goiana River estuary from 2006 to 2009.

Harrison and Whitfield, 2006; Kong and Ye, 2014; Wu et al., 2016).Salinity variations defined the estuarine gradient (Attrill and Rundle, 2002; Barletta and Dantas, 2016). In 2006, the dry season was very severe $(33.9 \pm 8.5 \mathrm{~mm})$, decreasing freshwater entering the estuary and significantly increasing salinity locally, with the greatest marine influence on the estuary of all years, similarly to other reports in the literature (Yin et al., 2004).
Water temperature and salinity are important abiotic variables, which together play a fundamental role in the distribution of aquatic biota, with the determination of ecoclines (Attrill and Rundle, 2002; Yin et al., 2004; Harrison and Whitfield, 2006; Nejrup and Pedersen, 2008; Barletta and Dantas, 2016; Dolbeth et al., 2016). Sudden and/or large changes in these parameters may compromise environmental quality over 


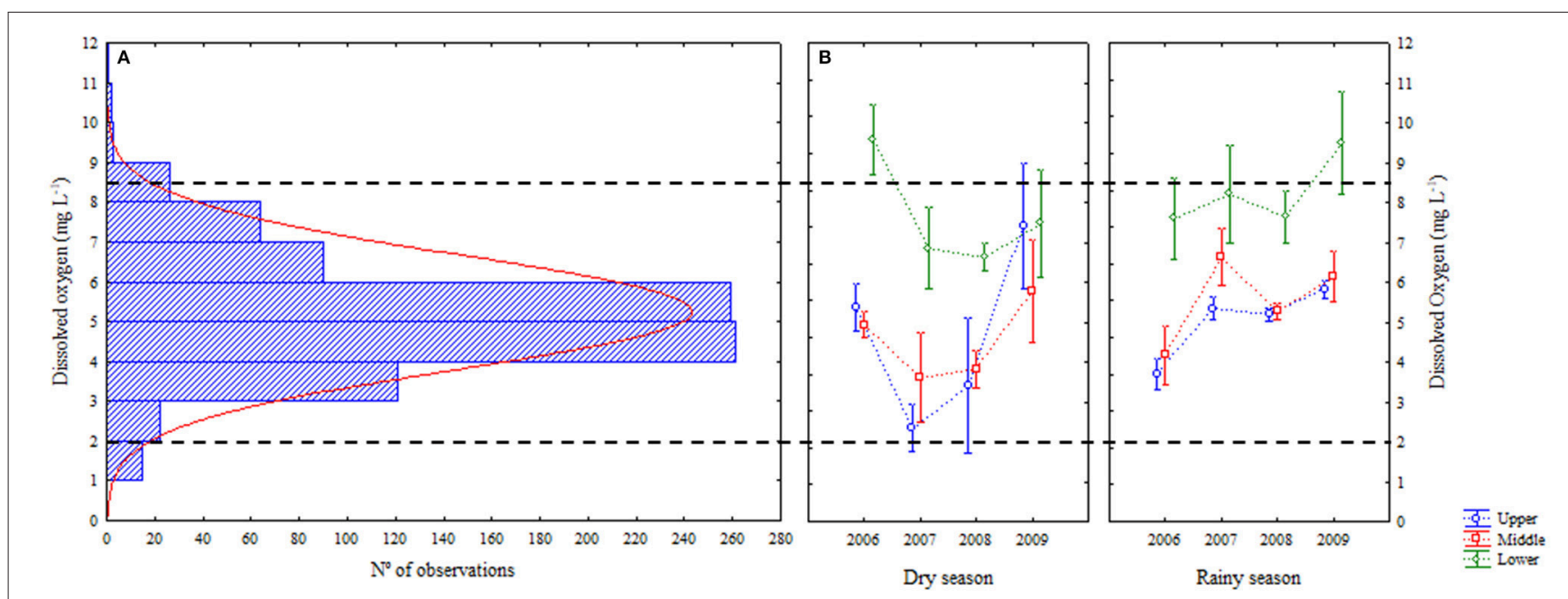

FIGURE 5 | (A) Histogram of observations ( $n=432$ ) for dissolved oxygen, following the normal distribution; (B) Average ( \pm standard deviation) of temporal (interannual and seasonal) variations of dissolved oxygen at the Goiana River estuary from 2006 to 2009 . Colour scale shows the levels of water quality according to this parameter.
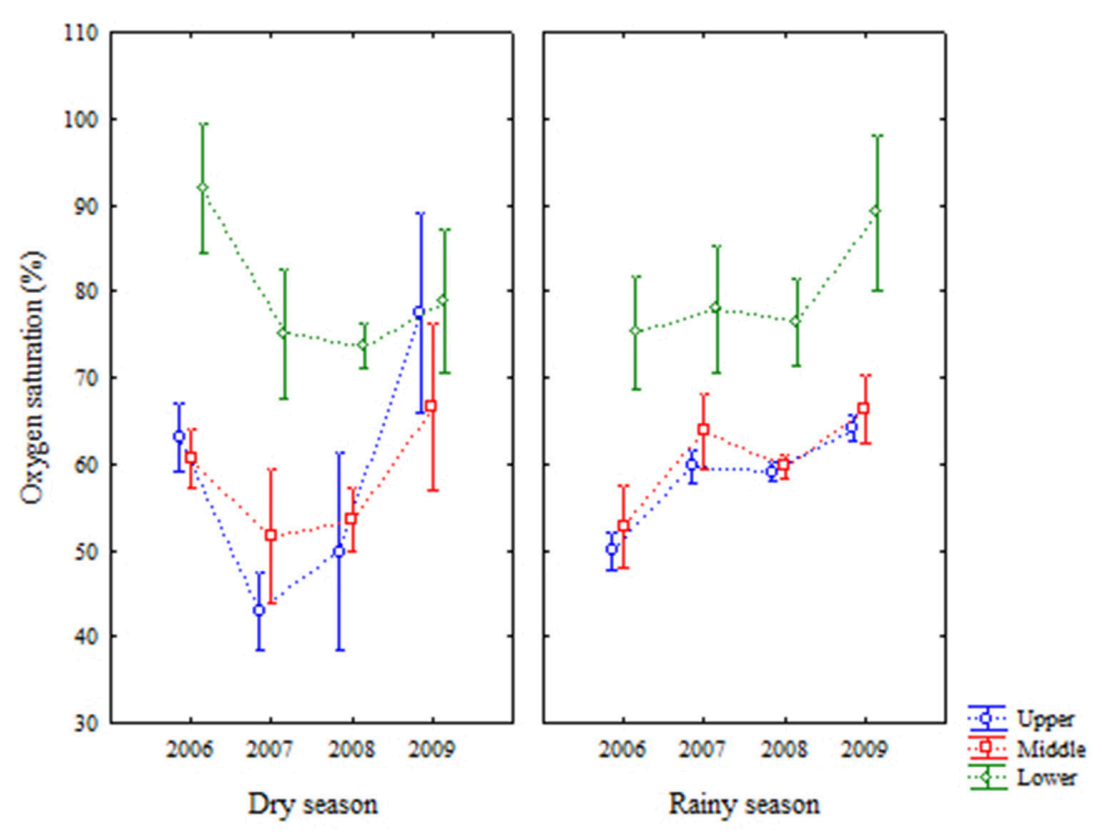

FIGURE 6 | Average ( \pm standard deviation) of temporal (interannual and seasonal) variations of oxygen saturation at the Goiana River estuary from 2006 to 2009.

time, as may change the composition and distribution of biota (Lucena-Moya and Duggan, 2017; Paul and Calliari, 2017), alteration of areas of high ecological importance considered nurseries (Barletta et al., 2005; Blaber, 2013), increase the effect of organic pollution on estuaries as well as the distribution of plastics and microplastics (Possatto et al., 2011; Ivar do Sul and Costa, 2013; Ivar do Sul et al., 2014; Lima et al., 2014), dilution of effluents (Govindasmy and Chandrasekaran, 1992; Uriarte and Villate, 2004; Whitehead et al., 2009; Telesh and Khlebovich, 2010), and absorption and accumulation of pollutants by biota (Tett et al., 2003; Roselli et al., 2013; Zhou et al., 2017).

Dissolved oxygen and oxygen saturation showed similar behaviours, although the water temperature also influenced oxygen saturation indexes. Temperature variation was small, being predominant the interdependence between the dissolved oxygen and its saturation (Nezlin et al., 2009; Shah and Pant, 2012). The oxygen contents were higher in the lower area of the estuary, where there is a greater influence of marine waters, more oxygenated (Tett et al., 2003; Yin et al., 2004; Mudge et al., 2007; 

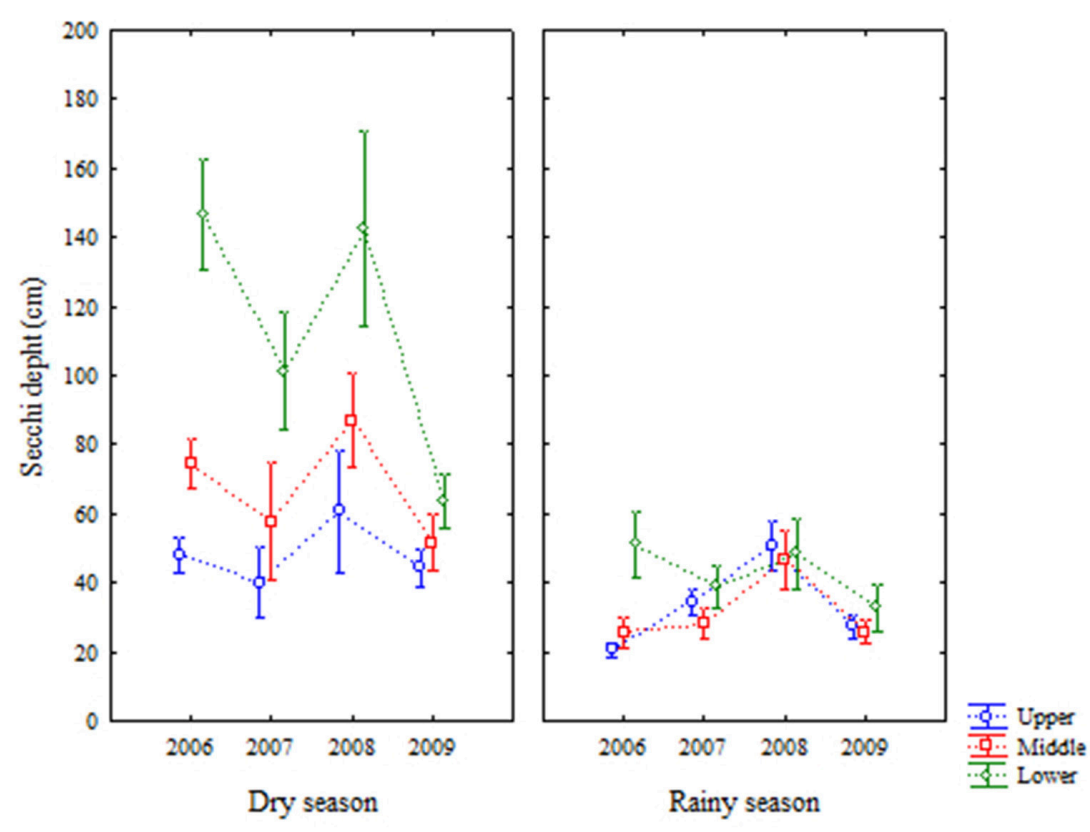

FIGURE 7 | Average ( \pm standard deviation) of temporal (interannual and seasonal) variations of Secchi depth at the Goiana River estuary from 2006 to 2009.

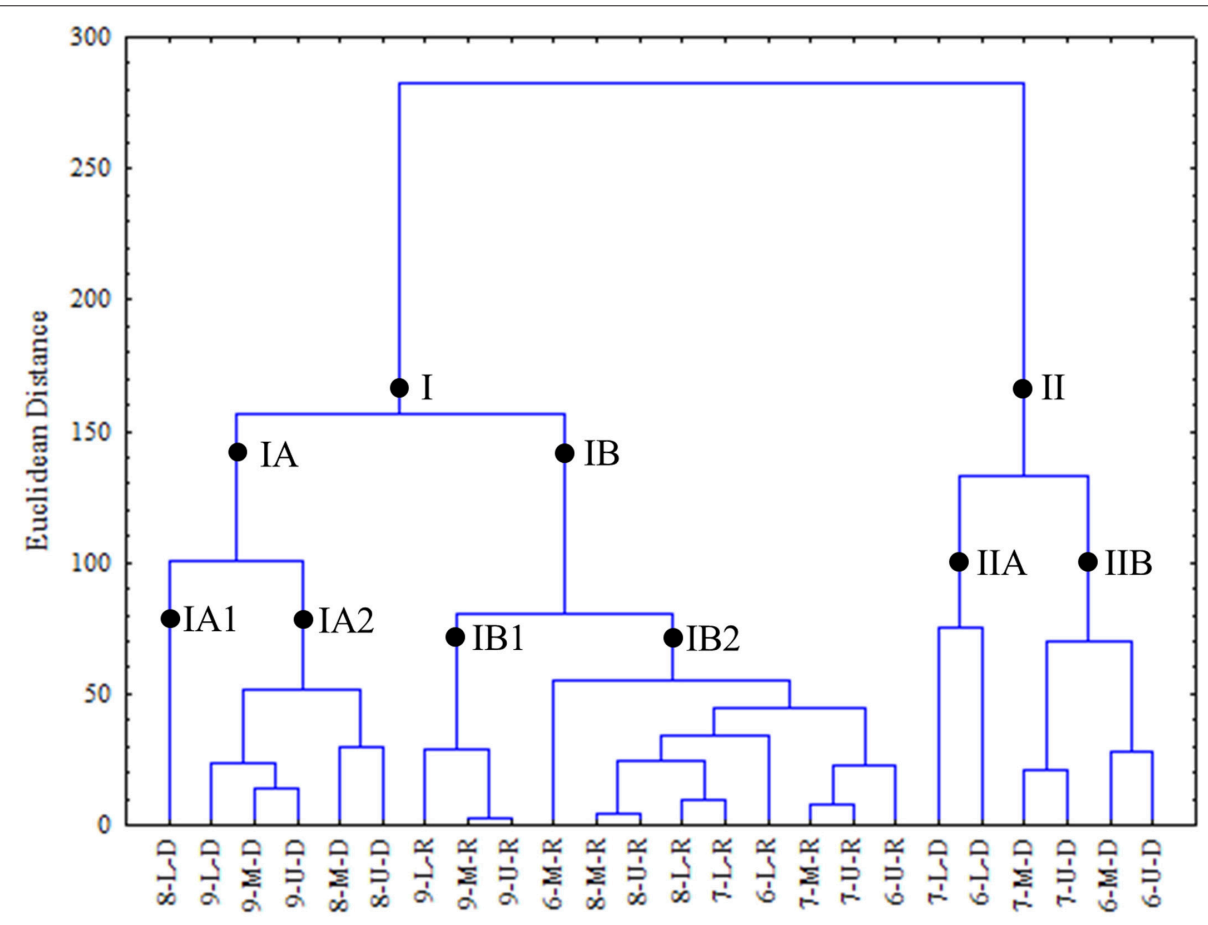

FIGURE 8 | Cluster of interannual seasonal averages of water quality parameters and rainfall at the Goiana River estuary through Euclidean distance. Legend for samples: first numeral represents the year (6 - 2006, 7 - 2007, 8 - 2008, 9 - 2009); second letter represents estuarine area (U, upper; M, middle; L, lower) and third letter represents season ( $D$, dry; $R$, rainy).

Zhang et al., 2010). Year 2009 presented an atypical character related to oxygen concentrations, due to the dry season of this year having similar precipitation indices of the rainy season of that year. Other works report an increase of oxygen related to the occurrence of increased rainfall (Delpla et al., 2011; Li et al., 2015). Rainfall events occurring mainly in tropical areas are 
important for water renewal and dilution of possible effluents, thus improving its quality (Delpla et al., 2011; Corbari et al., 2016; Delpla and Rodriguez, 2016). There was homogenization of the oxygen distributed, making the values measured for this parameter similar in all estuarine areas. The levels of dissolved oxygen recommended for aquatic conservation are above 4-5 mg $\mathrm{L}^{-1}$ (Conselho Nacional de Meio Ambiente, 2005; Breitburg et al., 2009; Osode and Okoh, 2009), being occasionally lower, resulting from anthropic interference.

Secchi depth presented higher values in dry season, when the water column is more stable, lower resuspension of particles, as well as lower flow sediment and particulate matter carried by runoff. In the rainy season as well as in dry season of 2009 , lower values are observed, due to the greater volume of

TABLE 2 | Eigenvalues used in the construction of PCA.

\begin{tabular}{lrr}
\hline & \multicolumn{2}{c}{ Eigenvalues } \\
\cline { 2 - 3 } Variables & Factor 1 & Factor 2 \\
\hline Water temperature & 0.744 & -0.523 \\
Salinity & 0.934 & 0.177 \\
Dissolved oxygen & 0.399 & 0.860 \\
Oxygen saturation & 0.526 & 0.788 \\
Secchi depth & -0.680 & 0.600 \\
Rainfall & 0.892 & -0.047 \\
Year & -0.095 & 0.291 \\
Area & 0.593 & 0.646 \\
Season & -0.736 & 0.595
\end{tabular}

The values in italics are the most important in the formation of the principal axis. rains, increasing the turbidity, and being able to shift primary production (Schlacher and Wooldridge, 1996; Kronvang et al., 2005; Devlin et al., 2008). The variation of solar radiation is probably not a determining factor because the estuary is located in a tropical area (Qasim et al., 1968; Kronvang et al., 2005).

\section{Episodic Hypoxia}

Regional legislation (Conselho Nacional de Meio Ambiente, 2005) establishes for estuarine environments, that hypoxia conditions are those in which the dissolved oxygen levels are $<3 \mathrm{mg} \mathrm{L}^{-1}$. This study used as basis the international literature, which adopt more conservative levels, being considered $<2 \mathrm{mg}$ $\mathrm{L}^{-1}$ the limit for hypoxia (Attrill and Power, 2000; Tett et al., 2003; Mudge et al., 2007; Breitburg et al., 2009; Zhang et al., 2010; Roselli et al., 2013).

Hypoxia in coastal waters can be of natural and/or anthropogenic origin and is defined by levels of dissolved oxygen $<2 \mathrm{mg} \mathrm{L}^{-1}$ and $<30 \%$ of oxygen saturation (Mudge et al., 2007; Breitburg et al., 2009; Zhang et al., 2010). In this study, there were some episodes of hypoxia (15 in 864 observations), mainly during the dry season, in the upper and middle areas of the estuary (Figure 5). In these moments, river flow and the renewal of waters was severely affected by lack of rainfall both along the basin and locally (Attrill and Power, 2000; Yin et al., 2004; Dai et al., 2006) Concentrations of dissolved oxygen in surface waters are regulated by the balance between production, consumption (respiration and other chemical reactions) and exchange with the atmosphere (Wannamaker and Rice, 2000; Uriarte and Villate, 2004). The decrease in renewal caused the consumption of available oxygen in water to almost its entirety. Also, less flow results in limited turbulence and consequently less diffusion from the atmosphere. Hypoxia is a typical consequence of continued

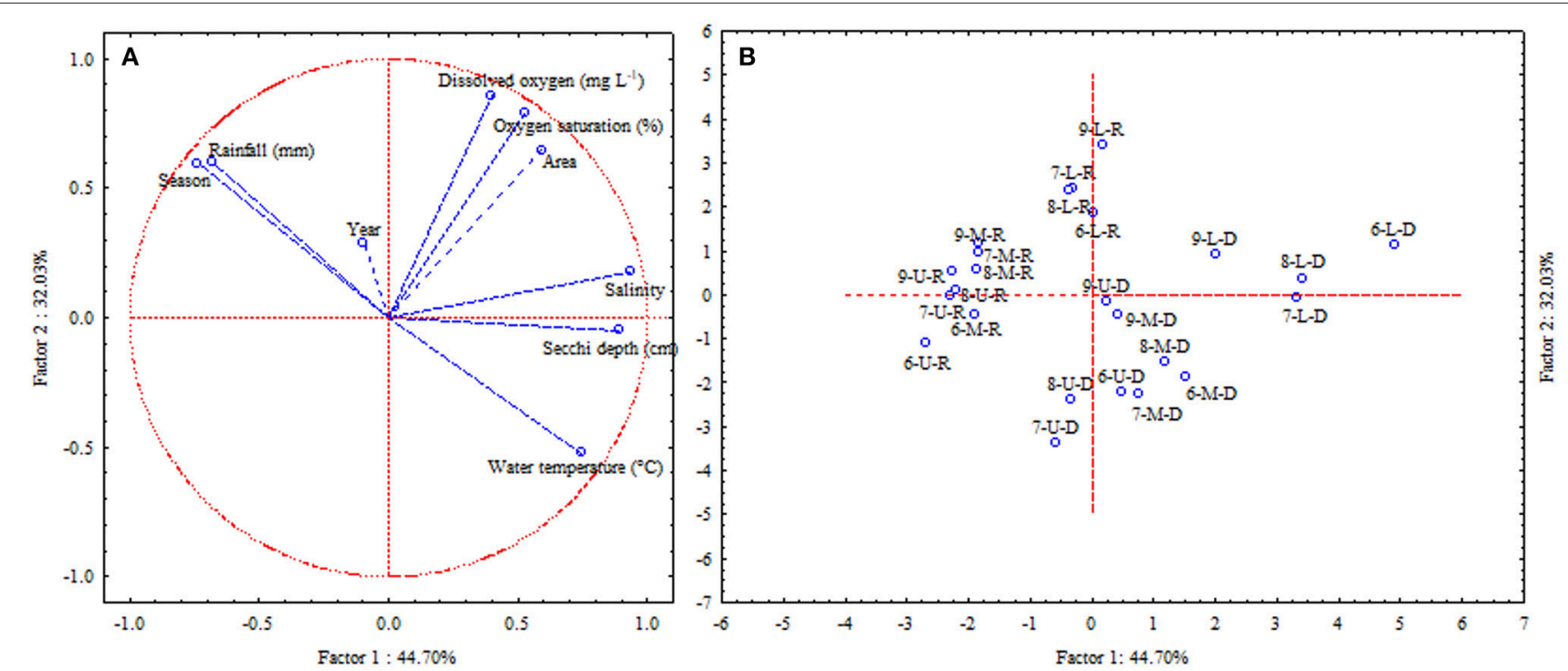

FIGURE 9 | (A) Weight graph (PCA) showing the contribution of environmental variables to the water quality patterns at the Goiana River estuary from 2006 to 2009. (B) Score graph (PCA) showing the contribution of environmental variables to the water quality patterns at the Goiana River estuary from 2006 to 2009 . Legend for samples: first numeral represents the year (6 - 2006, 7 - 2007, 8 - 2008, 9 - 2009); second letter represents estuarine area (U, upper; M, middle; L, lower) and third letter represents season ( $D$, dry; $R$, rainy). 
decline in water quality (Wannamaker and Rice, 2000; Schmidt et al., 2016; Qian et al., 2018). It may result in habitat degradation and habitat loss (Wannamaker and Rice, 2000; Tett et al., 2003; Mudge et al., 2007; Gelesh et al., 2016). In the world, a number of hypoxia cases have already been reported in scientific literature. Shallow and warm waters from tropical estuaries are particularly vulnerable (Attrill and Power, 2000; Wannamaker and Rice, 2000; Yin et al., 2004; Dai et al., 2006; Bianchi et al., 2010; Bourgault and Cyr, 2015; Costa and Barletta, 2016; Jeppesen et al., 2016; Schmidt et al., 2016).Hypoxic conditions will, eventually, be responsible for decrease in biological abundance and diversity (Uriarte and Villate, 2004; Ram et al., 2014; Jeppesen et al., 2016), altered growth and mortality rates of juvenile fish (Wannamaker and Rice, 2000; Ram et al., 2014), altered behaviour, feeding and other habits change (Zhang et al., 2010; Weinke and Biddanda, 2018), methane production (Gelesh et al., 2016). The phenomenon is, in addition, aggravated by acidification (Miller et al., 2016) and global warming (Zhang et al., 2010). All these changes concur for permanent environmental changes and, finally, resilience rupture at an ecosystem scale.

The samples analysed in the present work were taken from the main channel of the estuary, where water is expected to have the best possible chances of renewal and oxygen diffusion/production. In effect, most of the observations for dissolved oxygen were in a range considered safe for the environment (Figure 5). There is a higher than average chance that hypoxia is already installed at smaller tidal creeks and less turbulent reaches of the drainage system that composes the estuary (Ramos et al., 2011). If, the frequency, range and duration of such hypoxia episodes increase in the Goiana River estuary in the future, there will be cause of concern for the conservation of water resources and should therefore be closely monitored.

\section{Variables Interdependence}

The change in water quality resulting from the change in the amount of rainfall was noticed thanks to the interannual sampling carried out. Carefully planned sampling is also an important tool for the detection of cyclic phenomena, which are detected only at larger temporal scales (Karydis and Kitsiou, 2013), and a less intense but similar sample design is suggested for the water quality assessment of this estuary in order to detect long-term permanent changes due to anthropic interference.

Basin-wide to local rainfall volumes are the main factors determining the quantity and quality of estuarine waters (Karydis and Kitsiou, 2013; Corbari et al., 2016). Although it temporarily reduces sunlight penetration into the water column, limiting primary production (Qasim et al., 1968; Kronvang et al., 2005; Cloern et al., 2014), freshwater inputs promoted the increase of available dissolved oxygen, as well as the diffusion, dilution and transportation of effluents and pollutants (Yin et al., 2004; Brooks et al., 2006; Osode and Okoh, 2009; Zhang et al., 2010). In the dry seasons, the water quality drop is also observed, mainly due to lack of water renewal promoted by the rain (Attrill and Power, 2000; Dai et al., 2006).

Dissolved oxygen was the most important variable related to water quality in this study, highlighted in its important contribution to the formation of the PC2 axis (Figure 9; Table 2).
Several authors have developed studies in the area, which have not demonstrated that oxygen could a limiting factor for organisms' distribution. This might result from the still existing conservation status of the system or, due to the sampling in the main channel. For the demersal fish assemblages, salinity and temperature appears as the main limiting factors (Barletta et al., 2005; Dantas et al., 2010; Ramos et al., 2016).

\section{Managerial and Conservation Implications}

Water scarcity is a critical problem around the world. In Northeast South America there are few large river basins, so the numerous small estuaries along the coast are the most important source of water for the most diverse uses (World Health Organization, 1996). Rainfall is the most important factor in the renewal and maintenance of these waters (Schlacher and Wooldridge, 1996), causing considerable improvement in their quality (Karydis and Kitsiou, 2013; Corbari et al., 2016), however, of a temporary nature.

The important relationship dependence of the Goiana River estuary with rainfall to the renewal of its water resources was also observed in other estuaries. Mérigot et al. (2016) observed the same for four estuarine complexes in Brazil and Harrison (2004), in South Africa, in another 109 studied estuaries. The maintenance of these waters is crucial for the continuity of the provision of ecological services (Karydis and Kitsiou, 2013; Corbari et al., 2016).

Climatic events, such as above-average precipitation years (2008 and 2009), contribute in principle to improving environmental conditions (Bouvy et al., 1999; Jackson et al., 2001; Nijssen et al., 2001). However, changes in rainfall and freshwater discharge patterns from basins can increase freshwater flows, change the flow rate and increase sedimentary loads with potential to alter the morphology of the environments, as well as altering natural biogeochemical cycles, thus impacting habitats (Tett et al., 2003; Yin et al., 2004; Whitehead et al., 2009; Roselli et al., 2013). Since such changes are driven by deforestation of the basin soil and estuarine margins, consequences are permanent, although partially reversible if the vegetation is minimally restored.

The Goiana River estuary is under numerous human interferences. Like many other tropical estuaries, it is highly impacted by sugarcane plantations (Brockmeyer and Spitzy, 2011; Thorburn et al., 2011; Davis et al., 2013; de Melo Gurgel et al., 2016; Valera et al., 2016).

Tropical soils present low levels of organic matter, causing difficulties for their maintenance for the cultivation of sugarcane. Large quantities of fertilizers which are carried toward the estuarine channel by the rainfall is necessary for the yield of crops (Alexakis, 2011; Brockmeyer and Spitzy, 2011; Humbert, 2013), causing the consumption of the available dissolved oxygen in the water. The projected trend of change influenced by anthropogenic actions in global climate includes several events: water heating (change in chemical kinetics of reactions in the estuary, stratification of the water column, hypoxia); rising sea levels; reduction of water $\mathrm{pH}$ (acidification); loss/replacement of habitats (species migration, invasion of exotic species) and the expansion of the tropics (Attrill and Power, 2000; 
Mudge et al., 2007; Zhang et al., 2010; Statham, 2012; Madsen et al., 2014). The importance of environments such as tropical estuaries will be even more prominent in the near future, demanding a considerable understanding of the functioning of these ecosystems. In addition the demand for water resources tends to increase and surface water quality will become a priority (World Health Organization, 2014).

\section{FINAL REMARKS}

Our work assessed the water quality conditions at the main channel of Goiana River estuary from 2006 to 2009. The sample design used allowed for the detection of interannual changes in water quality due mainly from variations in rainfall patterns. It also corroborated previous ecological studies by confirming that the aquatic habitats of the main channel offer conditions to the maintenance of biological resources most of the time.

Water quality in study area remains overall reasonable, despite hypoxia events. These events should be seen as a warning sign of the sensitivity and vulnerability of this and other similar environments to human interferences (e.g., domestic effluents discharge, sugarcane irrigation, fertilization and milling effluents).

As a way to maintain environmental quality, measures to mitigate impacts on the aquatic habitats start with basin-wide mitigation actions and include the estuarine region. Soil use and occupation, as well as water uses (restoration of riparian vegetation, soil recovery, and effluents treatment before disposal) must be improved. Measures such as these are essential for the maintenance of ecosystem services offered by the estuary. There is uncertainty about the likely impacts on water quality due to changes in regional rainfall patterns-especially due to deforestation and increasing demands on water resources. Projects for new water supplies, urban drainage and water

\section{REFERENCES}

Alexakis, D. (2011). Assessment of water quality in the MessolonghiEtoliko and Neochorio region (West Greece) using hydrochemical and statistical analysis methods. Environ. Monit. Assess. 182, 397-413. doi: 10.1007/s10661-011-1884-2

Arruda-Santos, R. H., Schettini, C. A. F., Yogui, G. T., Maciel, D. C., and ZanardiLamardo, E. (2018). Sources and distribution of aromatic hydrocarbons in a tropical marine protected area estuary under influence of sugarcane cultivation. Sci. Total Environ. 624, 935-944. doi: 10.1016/j.scitotenv.2017.12.174

Attrill, M. J., and Power, M. (2000). Modelling the effect of drought on estuarine water quality. Water Res. 34, 1584-1594. doi: 10.1016/S0043-1354(99)00305-X

Attrill, M. J., and Rundle, S. D. (2002). Ecotone or ecocline: ecological boundaries in estuaries. Estuar. Coast. Shelf Sci. 55, 929-936. doi: 10.1006/ecss. 2002.1036

Barletta, M., Amaral, C. S., Corrêa, M. F. M., Guebert, F., Dantas, D. V., Lorenzi, L., et al. (2008). Factors affecting seasonal variations in demersal fish assemblages at an ecocline in a tropical-subtropical estuary. J. Fish Biol. 73, 1314-1336. doi: 10.1111/j.1095-8649.2008.02005.x

Barletta, M., and Costa, M. F. (2009). Living and non-living resources exploitation in a tropical semi-arid estuary. J. Coast. Res. 56, 371-375.

Barletta, M., Barletta-Bergan, A., Saint-Paul, U., and Hubold, G. (2005). The role of salinity in structuring the fish assemblages in a tropical estuary. J. Fish Biol. 66, 45-72. doi: 10.1111/j.0022-1112.2005.00582.x treatment systems will have to account for the effects of local climate change.

Rainfall is an important factor in promoting seasonal discharges and maintaining ecosystem health in regions with resources-limited watersheds, especially those where flow control is in place. Dry season is a critical period, where due to tropical temperatures and low water renewal, water quality can be severely reduced. As suggested by our results, regions that are most sensitive to environmental and socioeconomic changes and overuse of their water resources should pay more attention to changes in seasonal and climatic rainfall patterns, for they will condition water availability in the near future.

\section{AUTHOR CONTRIBUTIONS}

CC analyzed data and prepared the manuscript; MC secured funds, participated in field work and assisted in the preparation of the manuscript; DD participated in fieldwork and in early data processing and analysis; $\mathrm{MB}$ secured funds, designed the experiment, conduced fieldwork, analyzed data and assisted in the preparation of the manuscript; all authors have read and contributed to the final version of the text.

\section{ACKNOWLEDGMENTS}

Authors acknowledge CNPq, FACEPE, and CAPES for financial support in the form of scholarships and grants. $\mathrm{MC}$ and $\mathrm{MB}$ are CNPq Fellows.

\section{SUPPLEMENTARY MATERIAL}

The Supplementary Material for this article can be found online at: https://www.frontiersin.org/articles/10.3389/fmars. 2018.00301/full\#supplementary-material

Barletta, M., and Dantas, D. V. (2016). "Environmental Gradients," in Encyclopedia of Estuaries, ed M. J. Kennish (Amsterdam: Springer), 760.

Bianchi, T. S., DiMarco, S. F., Cowan, J. H., Hetland, R. D., Chapman, P., Day, J. W., et al. (2010). The science of hypoxia in the Northern Gulf of Mexico: a review. Sci. Total Environ. 408, 1471-1484. doi: 10.1016/j.scitotenv.2009. 11.047

Blaber, S. J. M. (2013). Fishes and fisheries in tropical estuaries: the last 10 years. Estuar. Coast. Shelf Sci. 135, 57-65. doi: 10.1016/j.ecss.2012.11.002

Bourgault, D., and Cyr, F. (2015). Hypoxia in the St. Lawrence Estuary: how a coding error led to the belief that "Physics controls spatial patterns." PLoS ONE 10:e0138858. doi: 10.1371/journal.pone.0138858

Bouvy, M., Molica, R., Oliveira, S., Marinho, M., and Beker, B. (1999). Dynamics of a toxic cyanobacterial bloom (Cylindrospermopsis raciborskii) in a shallow reservoir in the semi-arid region of northeast Brazil. Aquat. Microb. Ecol. 20, 285-297. doi: 10.3354/ame020285

Breitburg, D. L., Hondorp, D. W., Davias, L. A., and Diaz, R. J. (2009). Hypoxia, nitrogen, and fisheries: integrating effects across local and global landscapes. Ann. Rev. Mar. Sci. 1, 329-349. doi: 10.1146/annurev.marine.010908.163754

Brockmeyer, B., and Spitzy, A. (2011). Effects of sugar cane monocultures on origin and characteristics of dissolved organic matter in the Manguaba lagoon in northeast Brazil. Org. Geochem. 42, 74-83. doi: 10.1016/j.orggeochem.2010.10.009

Brooks, B. W., Riley, T. M., and Taylor, R. D. (2006). Water quality of effluentdominated ecosystems: ecotoxicological, hydrological, and management 
considerations. Hydrobiologia 556, 365-379. doi: 10.1007/s10750-0040189-7

Clarke, K. R., and Warwick, R. M. (2001). Change in Marine Communities: An Approach to Statistical Analysis an Interpretation. 2nd Edn. Plymouth: Primer-E.

Cloern, J. E., Foster, S. Q., and Kleckner, A. E. (2014). Phytoplankton primary production in the world's estuarine-coastal ecosystems. Biogeosciences 11, 2477-2501. doi: 10.5194/bg-11-2477-2014

Conselho Nacional de Meio Ambiente (2005). "Resolução no 357, de 17 de Março de 2005," in Diário Oficial da União n 053, de 18/03/2005 (Brasília), 58-63.

Corbari, C., Lassini, F., and Mancini, M. (2016). Effect of intense short rainfall events on coastal water quality parameters from remote sensing data. Cont. Shelf Res. 123, 18-28. doi: 10.1016/j.csr.2016.04.009

Costa, C. R., da Costa, M. F., Barletta, M., and Alves, L. H. B. (2017). Interannual water quality changes at the head of a tropical estuary. Environ. Monit. Assess. 189:628. doi: 10.1007/s10661-017-6343-2

Costa, M. F., and Barletta, M. (2016). Special challenges in the conservation of fishes and aquatic environments of South America. J. Fish Biol. 89, 4-11. doi: $10.1111 /$ jfb. 12970

CPRH-Agência Estadual de Meio Ambiente e Recursos Hídricos (2015). Relatório de Monitoramento da Qualidade da Água de Bacias Hidrográficas do Estado de Pernambuco - 2014. Recife.

Dai, M., Guo, X., Zhai, W., Yuan, L., Wang, B., Wang, L., et al. (2006). Oxygen depletion in the upper reach of the Pearl River estuary during a winter drought. Mar. Chem. 102, 159-169. doi: 10.1016/j.marchem.2005.09.020

Dantas, D. V., Barletta, M., Costa, M. F., Barbosa-Cintra, S. C. T., Possatto, F. E., Ramos, J. A., et al. (2010). Movement patterns of catfishes (Ariidae) in a tropical semi-arid estuary. J. Fish Biol. 76, 2540-2557. doi: 10.1111/j.1095-8649.2010.02646.x

Davis, A. M., Thorburn, P. J., Lewis, S. E., Bainbridge, Z. T., Attard, S. J., Milla, R., et al. (2013). Environmental impacts of irrigated sugarcane production: herbicide run-off dynamics from farms and associated drainage systems. Agric. Ecosyst. Environ. 180, 123-135. doi: 10.1016/j.agee.2011.06.019

de Melo Gurgel, P. M., Navoni, J. A., de Morais Ferreira, D., and do Amaral, V. S. (2016). Ecotoxicological water assessment of an estuarine river from the Brazilian Northeast, potentially affected by industrial wastewater discharge. Sci. Total Environ. 572, 324-332. doi: 10.1016/j.scitotenv.2016.08.002

Delpla, I., Baurès, E., Jung, A. V., and Thomas, O. (2011). Impacts of rainfall events on runoff water quality in an agricultural environment in temperate areas. Sci. Total Environ. 409, 1683-1688. doi: 10.1016/j.scitotenv.2011. 01.033

Delpla, I., and Rodriguez, M. J. (2016). Experimental disinfection by-product formation potential following rainfall events. Water Res. 104, 340-348. doi: 10.1016/j.watres.2016.08.031

Devlin, M. J., Barry, J., Mills, D. K., Gowen, R. J., Foden, J., Sivyer, D., et al. (2008). Relationships between suspended particulate material, light attenuation and Secchi depth in UK marine waters. Estuar. Coast. Shelf Sci. 79, 429-439. doi: 10.1016/j.ecss.2008.04.024

Dolbeth, M., Vendel, A. L., Baeta, A., Pessanha, A., and Patrício, J. (2016). Exploring ecosystem functioning in two Brazilian estuaries integrating fish diversity, species traits and food webs. Mar. Ecol. Prog. Ser. 560, 41-55. doi: $10.3354 /$ meps 11895

Garlipp, A. B., Souza Neto, J. A., Valença, L. M. M., and Manso, V. A. V. (2010). Variabilidade histórica de elementos maiores e traços em sedimentos estuarinos sob influência da carcinicultura: o sistema estuarino Goiana-Megaó, Pernambuco, Brasil. Estud. Geológicos 20, 3-18. doi: 10.18190/1980-8208/estudosgeologicos.v20n2p3-18

Gelesh, L., Marshall, K., Boicourt, W., and Lapham, L. (2016). Methane concentrations increase in bottom waters during summertime anoxia in the highly eutrophic estuary, Chesapeake Bay, U.S.A. Limnol. Oceanogr. 61, S253S266. doi: 10.1002/lno.10272

Govindasmy, R., and Chandrasekaran, S. (1992). Effect of humic acids on the growth, yield and nutrient content of sugarcane. Sci. Total Environ. 117-118, 575-581. doi: 10.1016/0048-9697(92)90122-9

Harrison, T. D. (2004). Physico-chemical characteristics of South African estuaries in relation to the zoogeography of the region. Estuar. Coast. Shelf Sci. 61, 73-87. doi: 10.1016/j.ecss.2004.04.005
Harrison, T. D., and Whitfield, A. K. (2006). Temperature and salinity as primary determinants influencing the biogeography of fishes in South African estuaries. Estuar. Coast. Shelf Sci. 66, 335-345. doi: 10.1016/j.ecss.2005.09.010

Haynes, D., Brodie, J., Waterhouse, J., Bainbridge, Z., Bass, D., and Hart, B. (2007). Assessment of the water quality and ecosystem health of the great barrier reef (Australia): conceptual models. Environ. Manage. 40, 993-1003. doi: 10.1007/s00267-007-9009-y

Humbert, R. P. (2013). “Chapter I - Factors affecting the growth of sugar cane," in The Growing of Sugar Cane (Amsterdam: Elsevier), 12-52.

Ivar do Sul, J. A., and Costa, M. F. (2013). Plastic pollution risks in an estuarine conservation unit. J. Coast. Res. 65, 48-53. doi: 10.2112/SI65-009.1

Ivar do Sul, J. A., Costa, M. F., Silva-Cavalcanti, J. S., and Araújo, M. C. (2014). Plastic debris retention and exportation by a mangrove forest patch. Mar. Pollut. Bull. 78, 252-257. doi: 10.1016/j.marpolbul.2013.11.011

Jackson, R. B., Carpenter, S. R., Dahm, C. N., McKnight, D. M., Naiman, R. J., Postel, S. L., et al. (2001). Water in a changing world. Ecol. Appl. 11, 1027-1045. doi: 10.1890/1051-0761(2001)011[1027:WIACW]2.0.CO;2

Jeppesen, R., Rodriguez, M., Rinde, J., Haskins, J., Hughes, B., Mehner, L., et al. (2016). Effects of hypoxia on fish survival and oyster growth in a highly eutrophic estuary. Estuar. Coasts 41, 89-98. doi: 10.1007/s12237-016-0169-y

Karydis, M., and Kitsiou, D. (2013). Marine water quality monitoring: a review. Mar. Pollut. Bull. 77, 23-36. doi: 10.1016/j.marpolbul.2013.09.012

Kennish, M. J. (1991). Ecology of Estuaries: Anthropogenic Effects. Boca Raton, FL: CRC Press.

Kennish, M. J. (1998). Pollution Impacts on Marine Biotic Communities. Boca Raton, FL: CRC Press.

Kitsiou, D., and Karydis, M. (2011). Coastal marine eutrophication assessment: a review on data analysis. Environ. Int. 37, 778-801. doi: 10.1016/j.envint.2011.02.004

Kjerfve, B. (1990). Manual for Investigation of Hydrological Processes in Mangrove Ecosystems. Paris: Unesco/UNDP Regional Project; Research and its application to the management of the mangroves of Asis and the Pacific (RAS/86/120).

Kong, X., and Ye, S. (2014). The impact of water temperature on water quality indexes in north of Liaodong Bay. Mar. Pollut. Bull. 80, 245-249. doi: 10.1016/j.marpolbul.2013.12.017

Kronvang, B., Jeppesen, E., Conley, D. J., Søndergaard, M., Larsen, S. E., Ovesen, N. B., et al. (2005). Nutrient pressures and ecological responses to nutrient loading reductions in Danish streams, lakes and coastal waters. J. Hydrol. 304, 274-288. doi: 10.1016/j.jhydrol.2004.07.035

Li, X., Huang, T., Ma, W., Sun, X., and Zhang, H. (2015). Effects of rainfall patterns on water quality in a stratified reservoir subject to eutrophication: implications for management. Sci. Total Environ. 521-522, 27-36. doi: 10.1016/j.scitotenv.2015.03.062

Lima, A. R., Costa, M. F., and Barletta, M. (2014). Distribution patterns of microplastics within the plankton of a tropical estuary. Environ. Res. 132, 146-155. doi: 10.1016/j.envres.2014.03.031

Lucena-Moya, P., and Duggan, I. C. (2017). Correspondence between zooplankton assemblages and the Estuary environment classification system. Estuar. Coast. Shelf Sci. 184, 1-9. doi: 10.1016/j.ecss.2016.10.028

Madsen, H., Lawrence, D., Lang, M., Martinkova, M., and Kjeldsen, T. R. (2014). Review of trend analysis and climate change projections of extreme precipitation and floods in Europe. J. Hydrol. 519, 3634-3650. doi: 10.1016/j.jhydrol.2014.11.003

Mérigot, B., Lucena Frédou, F., Pontes Viana, A., Padovani Ferreira, B., do Nascimento Costa Junior, E., Beserra da Silva Júnior, C. A., et al. (2016). Fish assemblages in tropical estuaries of northeast Brazil: a multi-component diversity approach. Ocean Coast. Manag. 143, 175-183. doi: 10.1016/j.ocecoaman.2016.08.004

Miller, S. H., Breitburg, D. L., Burrell, R. B., and Keppel, A. G. (2016). Acidification increases sensitivity to hypoxia in important forage fishes. Mar. Ecol. Prog. Ser. 549, 1-8. doi: 10.3354/meps11695

Mudge, S. M., Icely, J. D., and Newton, A. (2007). Oxygen depletion in relation to water residence times. J. Environ. Monit. 9, 1194-1198. doi: 10.1039/b70 $8178 \mathrm{~b}$

Nejrup, L. B., and Pedersen, M. F. (2008). Effects of salinity and water temperature on the ecological performance of Zostera marina. Aquat. Bot. 88, 239-246. doi: 10.1016/j.aquabot.2007.10.006 
Nezlin, N. P., Kamer, K., Hyde, J., and Stein, E. D. (2009). Dissolved oxygen dynamics in a eutrophic estuary, Upper Newport Bay, California. Estuar. Coast. Shelf Sci. 82, 139-151. doi: 10.1016/j.ecss.2009.01.004

Nijssen, B., O’Donnell, G. M., Hamlet, A. F., and Lettenmaier, D. P. (2001). Hydrologic sensitivity of global rivers to climate change. Clim. Change 50, 143-175.

Osode, A. N., and Okoh, A. I. (2009). Impact of discharged wastewater final effluent on the physicochemical qualities of a receiving watershed in a suburban community of the eastern cape province. Clean Soil Air Water 37, 938-944. doi: 10.1002/clen.200900098

Paul, S., and Calliari, D. (2017). Salinity and temperature tolerances of Neomysis americana (Crustacea: Mysida) sub adults: perspectives on vulnerability, and distribution in South America. J. Exp. Mar. Bio. Ecol. 486, 373-378. doi: 10.1016/j.jembe.2016.10.027

Possatto, F. E., Barletta, M., Costa, M. F., Ivar do Sul, J. A., and Dantas, D. V. (2011). Plastic debris ingestion by marine catfish: an unexpected fisheries impact. Mar. Pollut. Bull. 62, 1098-1102. doi: 10.1016/j.marpolbul.2011.01.036

Qasim, S. Z., Bhattathiri, P. M. A., and Abidi, S. A. (1968). Solar radiation and its penetration in a tropical estuary. J. Exp. Mar. Bio. Ecol. 2, 87-103. doi: 10.1016/0022-0981(68)90015-4

Qian, W., Gan, J., Liu, J., He, B., Lu, Z., Guo, X., et al. (2018). Current status of emerging hypoxia in a eutrophic estuary: the lower reach of the Pearl River Estuary, China. Estuar. Coast. Shelf Sci. 205, 58-67. doi: 10.1016/j.ecss.2018.03.004

Ram, A., Jaiswar, J. R. M., Rokade, M. A., Bharti, S., Vishwasrao, C., and Majithiya, D. (2014). Nutrients, hypoxia and Mass Fishkill events in Tapi Estuary, India. Estuar. Coast. Shelf Sci. 148, 48-58. doi: 10.1016/j.ecss.2014.06.013

Ramos, J. A., Barletta, M., Dantas, D. V., and Costa, M. F. (2016). Seasonal and spatial ontogenetic movements of Gerreidae in a Brazilian tropical estuarine ecocline and its application for nursery habitat conservation. J. Fish Biol. 89, 696-712. doi: $10.1111 /$ jfb.12872

Ramos, J. A., Barletta, M., Dantas, D. V., Lima, A. R., and Costa, M. F. (2011). Influence of moon phase on fish assemblages in estuarine mangrove tidal creeks. J. Fish Biol. 78, 344-354. doi: 10.1111/j.1095-8649.2010.02851.x

Roselli, L., Cañedo-Argüelles, M., Costa Goela, P., Cristina, S., Rieradevall, M., D'Adamo, R., et al. (2013). Do physiography and hydrology determine the physico-chemical properties and trophic status of coastal lagoons? A comparative approach. Estuar. Coast. Shelf Sci. 117, 29-36. doi: 10.1016/j.ecss.2012.09.014

Schlacher, T. A., and Wooldridge, T. H. (1996). Ecological responses to reductions in freshwater supply and quality in South Africa's estuaries: lessons for management and conservation. J. Coast. Conserv. 2, 115-130.

Schmidt, S., Bernard, C., Escalier, J.-M., Etcheber, H., and Lamouroux, M. (2016). Assessing and managing the risks of hypoxia in transitional waters: a case study in the tidal Garonne River (South-West France). Environ. Sci. Pollut. Res. 24, 3251-3259. doi: 10.1007/s11356-016-7654-5

Shah, B. P., and Pant, B. R. (2012). Water quality assessment of sirsiya river. Nepal J. Sci. Technol. 13, 141-146. doi: 10.3126/njst.v13i2.7727

Silva, E. M., Costa, M. F., and Barletta, M. (2013). Small-scale water quality monitoring networks. J. Coast. Res. 165, 1218-1223. doi: 10.2112/SI65-206.1

Statham, P. J. (2012). Nutrients in estuaries - an overview and the potential impacts of climate change. Sci. Total Environ. 434, 213-227. doi: 10.1016/j.scitotenv.2011.09.088

Telesh, I. V., and Khlebovich, V. V. (2010). Principal processes within the estuarine salinity gradient: a review. Mar. Pollut. Bull. 61, 149-155. doi: 10.1016/j.marpolbul.2010.02.008
Tett, P., Gilpin, L., Svendsen, H., Erlandsson, C. P., Larsson, U., Kratzer, S., et al. (2003). Eutrophication and some European waters of restricted exchange. Cont. Shelf Res. 23, 1635-1671. doi: 10.1016/j.csr.2003.06.013

Thorburn, P. J., Biggs, J. S., Attard, S. J., and Kemei, J. (2011). Environmental impacts of irrigated sugarcane production: nitrogen lost through runoff and leaching. Agric. Ecosyst. Environ. 144, 1-12. doi: 10.1016/j.agee.2011.08.003

Uriarte, I., and Villate, F. (2004). Effects of pollution on zooplankton abundance and distribution in two estuaries of the Basque coast (Bay of Biscay). Mar. Pollut. Bull. 49, 220-228. doi: 10.1016/j.marpolbul.2004.02.010

Valera, C. A., Valle Junior, R. F., Varandas, S. G. P., Sanches Fernandes, L. F., and Pacheco, F. A. L. (2016). The role of environmental land use conflicts in soil fertility: a study on the Uberaba River basin, Brazil. Sci. Total Environ. 562, 463-473. doi: 10.1016/j.scitotenv.2016.04.046

Wannamaker, C. M., and Rice, J. A. (2000). Effects of hypoxia on movements and behavior of selected estuarine organisms from the southeastern United States. J. Exp. Mar. Bio. Ecol. 249, 145-163. doi: 10.1016/S0022-0981(00) 00160-X

Weinke, A. D., and Biddanda, B. A. (2018). From bacteria to fish: ecological consequences of seasonal hypoxia in a great lakes estuary. Ecosystems 21, 426-442. doi: 10.1007/s10021-017-0160-x

Whitehead, P. G., Wilby, R. L., Battarbee, R. W., Kernan, M., and Wade, A. J. (2009). A review of the potential impacts of climate change on surface water quality. Hydrol. Sci. J. 54, 101-123. doi: 10.1623/hysj.54.1.101

World Health Organization (1996). "Water quality assessments - a guide to use of biota, sediments and water," in Environmental Monitoring. 2nd Edn., D. Chapman (Cambridge: E\&FN Spon).

World Health Organization (2011). Guidelines for Drinking-water Quality. Geneva: WHO Library Cataloguing-in-Publication Data.

World Health Organization (2014). Progress on Sanitation and Drinking Water 2014 Update. Geneva: WHO Library Cataloguing in Publication Data.

Wu, S., Cheng, H., Xu, Y. J., Li, J., and Zheng, S. (2016). Decadal changes in bathymetry of the Yangtze River Estuary: human impacts and potential saltwater intrusion. Estuar. Coast. Shelf Sci. 182, 158-169. doi: 10.1016/j.ecss.2016.10.002

Yin, K., Lin, Z., and Ke, Z. (2004). Temporal and spatial distribution of dissolved oxygen in the Pearl River Estuary and adjacent coastal waters. Cont. Shelf Res. 24, 1935-1948. doi: 10.1016/j.csr.2004.06.017

Zhang, J., Gilbert, D., Gooday, A. J., Levin, L., Naqvi, S. W. A., Middelburg, J. J., et al. (2010). Natural and human-induced hypoxia and consequences for coastal areas: synthesis and future development. Biogeosciences 7, 1443-1467. doi: 10.5194/bg-7-1443-2010

Zhou, Y., Zhang, W., Guo, Z., and Zhang, L. (2017). Effects of salinity and copper co-exposure on copper bioaccumulation in marine rabbitfish Siganus oramin. Chemosphere 168, 491-500. doi: 10.1016/j.chemosphere.2016.11.003

Conflict of Interest Statement: The authors declare that the research was conducted in the absence of any commercial or financial relationships that could be construed as a potential conflict of interest.

Copyright () 2018 Costa, Costa, Dantas and Barletta. This is an open-access article distributed under the terms of the Creative Commons Attribution License (CC BY). The use, distribution or reproduction in other forums is permitted, provided the original author(s) and the copyright owner(s) are credited and that the original publication in this journal is cited, in accordance with accepted academic practice. No use, distribution or reproduction is permitted which does not comply with these terms. 